\title{
Hydro-geochemical Evaluation of Groundwater for Its Suitability to Various Uses; A Case Study of a Small Mountainous River Basin in Western Ghats, South India
}

\author{
Jayamohan Das ${ }^{1 *}$, Dr. Arun ${ }^{2}$, Dr. Resmi ${ }^{3}$, Athira Murali $^{4}$ \\ ${ }^{1,2,3,4}$ Centre for Water Resources Development and Management, Kozhikode \\ EmailID: jayamohandasdl@gmail ${ }^{1} . c o m$, arun@cwrdm.org ${ }^{2}$
}

\begin{abstract}
Groundwater is a major source of water for agricultural and domestic uses and also for other development activities. Therefore, groundwater quality including its, seasonal variations and its suitability for drinking, irrigation and industrial usage are evaluated. In this study, 27 groundwater samples were collected from the basin during the three seasons. The samples were analysed for various physico-chemical parameters and major ions. The analysis shows that most of the samples are acidic in nature. Based on analytical results, Gibbs diagram, Wilcox, piper and WQI were determined for suitability irrigation and drinking use. According to, Gibbs diagram majority of the samples fall in the rock and evaporation dominance controlling the groundwater chemistry, the piper diagram shows that $\mathrm{Ca}-\mathrm{HCO}_{3}$ mixed $\mathrm{CaNaHCO}_{3}$ and $\mathrm{NaCl}$ type dominated. The suitability of groundwater for irrigation were determined by analysing SAR, Na \%, MHR, PI and the suitability of water for drinking were determined by water quality index. It has been concluded that, the groundwater in the basin is good for drinking as well as and irrigation purposes but mostly not suitable for industrial purposes. Besides this, few of the samples which are found not suitable for irrigation and drinking purposes may be due to anthropogenic intervention.
\end{abstract}

Key words- Neyyar basin, Gibbs and piper diagram, WQI, SAR, and Permeability index

\section{INTRODUCTION}

The water is one of the essential needs for the growing population in the world. Water is needed for industrial, domestic, environmental, recreational, agricultural and other purposes. Due to the growth in population and economic development, the demand for water has increased by $400 \%$ between 1940 and 1990, globally [1]. The demand of groundwater resources also has continued to increase in most parts of the world, and many areas experience shortage of freshwater. An estimate by the United Nations reveals that, by the year 2025 two third of humanity will face the shortage of freshwater. Another study indicates that the world population without safe drinking water may rise to 2.3 billion in 2030 unless specific efforts are put in. At present one third of the world population is facing water stress. Many studies have been conducted to manage the human needs to balance with the supply from natural resources and the ability of nature to provide these resources in aneconomic manner. In turn, many countries, especially the developed countries in the world have accelerated rain water harvesting as well as artificial recharge methods in their area and benefited by the same. In developing countries the awareness and adoption has occurred only during the last 10-20 years. Several studies are being carried out in the field of groundwater development and management. Based on the geomorphological indicators and hydrological characteristics delineated from the satellite imageries, they have demarcated the probable recharge and discharge sites. Numerical modelling techniques were employed by different workers with the help of groundwater levels and water quality parameters as the input data [2][3][4][5].Groundwater and solute transport, as well as the flow along fresh-saline boundary conditions were analysed by employing these models. India has only $4 \%$ of the run-off compared to the rivers of the world and it is high time to concentrate on micro level studies for the effective conservation 
and sustainable management of the available water resources.

Thiruvananthapuram district, the southernmost district of Kerala, is one of the fast-developing administrative divisions of the state. At present major part of the water demand for 24 grama panchayats, of the Neyyar river basin is being met from groundwater. The basin is affected by the in-stream as well as flood plain mining practices. The purpose of this study is to: present the use of the WQI as a tracing tool for assessing the suitability for drinking purpose, evaluate the groundwater resources for irrigation purposes, and classify the hydrogeochemical outline of groundwater resource in Neyyar basin, Thiruvananthapuram.

\section{MATERIALS AND METHODS}

\subsection{Study Area}

Thiruvananthapuram, formerly known as Travancore, is the capital of the state of Kerala. Thiruvananthapuram district is situated between north latitudes $8^{0} 17^{\prime}$ 'and $8^{0} 54^{\prime}$ and east longitudes $76^{\circ} 41^{\prime}$ and $77^{0} 17$ '. The total area of the district is 2192 sq.km as the district stretches from north to south with the Arabian Sea in the west side; the relative humidity is generally high. It rises up to about $95 \%$ during the south-west monsoon. The present study area lies between $77^{\circ} 04^{\prime}-77^{\circ} 19^{\prime}$ E longitudes and $08^{\circ} 31^{\prime}-08^{\circ} 52^{\prime} \mathrm{N}$ latitudes. The study area mainly drained by Neyyar River, the southernmost river of the Kerala state, has its origin in the Agastya Mala. The average temperature in the study area ranges between 28 to $30{ }^{\circ} \mathrm{C}$. The basin receives rain during the South-West and North-East monsoons; highland region receives 30 to $40 \mathrm{~cm}$ rain annually and experiences a humid tropical climate.

The geological development can be grouped into four units, namely (i) Crystalline rocks of Archaen age (ii) Sedimentary rock of Tertiary age (iii) Laterite capping the crystalline and sedimentaries and (iv) Recent to sub-recent sediments forming the low-lying

\subsubsection{Temperature}

The temperature of the water is important because it affects the amount of dissolved oxygen in the water, as the temperature decreases the amount of oxygen dissolved in water increases. The minimum maximum temperature values were ranged from 26.529.9, 26.2-29.4, and 26.5-29.8 during three seasons areas and rivers valleys. The study area mainly consists of crystalline rocks of Archaen age comprising of gneisses and charnockite-Khondalite suite blanketed by fairly thick laterite capping with lenses of graphite, alluvium and soil. The thickness of laterite capping increases from higher altitude to lower altitude [6]. The main rock types in the area are charnockite, khondalite with veins of pegmatite, pyroxene granulite, garnet-biotite gneiss, garnet sillimanite gneiss, calc-granulites and quartzite. Dykes of dolerite and gabbroic composition follow the major structural trends.

\subsection{Methodology}

The study area base maps were scanned and digitized from the survey of India (SOI) Top sheets No.58H/02, 58H/03 and 58H/06. ArcGIS®10.3 software was used to analyze the spatial data on groundwater quality [7]. A total of 27 ground water sampling spots were fixed in Neyyar river basin and water samples were collected during three seasons (per-monsoon, monsoon and post-monsoon) from Neyyar river basin. The location of sampling spots in Figure 1.

Some parameters like $\mathrm{pH}, \mathrm{EC}$, TDS and salinity were measured in situ using field equipments all other water quality parameters were analyzed at the lab as per the standard proposed by the American Public Health Association [8]. The samples for analysis were collected as per the protocol. The water quality guideline values were obtained from World Health Organization [9] and Indian Standard institute [10] for agricultural and domestic purposes.

\section{RESULTS AND DISCUSSION}

\subsection{Drinking Suitability}

The statistics of minima-maxima of physico-chemical characteristics, major ions concentrations of ground water samples during the three seasons are tabulated in Table 1.

Temperature was found to be highest with value of $29.9^{\circ} \mathrm{C}$ at sample 4 during Pre-monsoon and minimal value of $26.2{ }^{\circ} \mathrm{C}$ was observed at sample 24 during monsoon season.

Temperature is also responsible for the reproduction of aquatic animals, also for photosynthesis of plants and development in aquatic organisms, a moderate 


\section{Available online at www.ijrat.org}

amount of temperature is essential for all living things to sustain their life in this planet.

\subsection{2 $\mathrm{pH}$}

The $\mathrm{pH}$ of water is extremely significant, which maintain the concentration of hydrogen and hydroxyl ions in water. The standard values of $\mathrm{pH}$ for drinking water specified by BIS and WHO is 6.5-8.5. $\mathrm{pH}$ obtains intensity of acidity or alkalinity and the concentration of ions in water. The $\mathrm{P}^{\mathrm{H}}$ values ranged from 4.77-6.92, 4.83-7.84 and 4.65-7.82 during the three seasons. Higher $\mathrm{pH}$ values of 7.84 were found in sample 3 and minimum values of 4.65 were found in sample 1 with an average value of 6.02. $\mathrm{pH}$ below 6.5 may causes corrosion in pipes.

The $\mathrm{pH}$ values varies from 4.65 -7.84 (Table 1), which clearly shows that the groundwater in the study area is slightly acidic in nature. This may be due to the anthropogenic intervention and other natural occurrences in the study area.

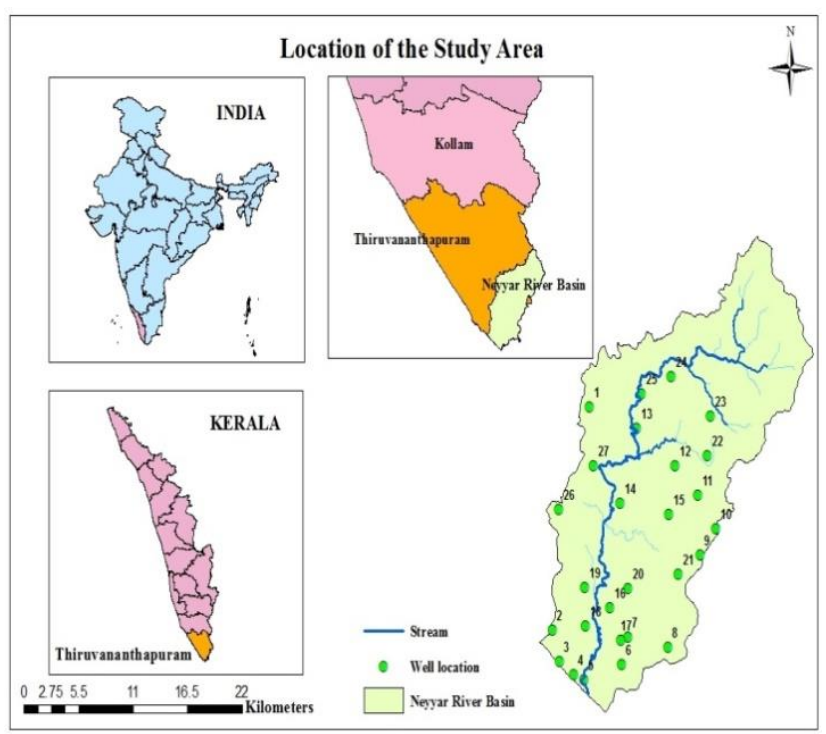

Figure: 1 sampling spot location map

Table: 1 Statics of Minima-Maxima specification on drinking water in study area

\begin{tabular}{|c|c|c|c|c|c|c|c|c|}
\hline \multirow{2}{*}{ Specification } & \multicolumn{2}{|c|}{ Pre-Monsoon } & \multicolumn{2}{|c|}{ Monsoon } & \multicolumn{2}{|c|}{ Post-Monsoon } & \multirow{2}{*}{$\begin{array}{l}\text { WHO } \\
\text { Standard } \\
(2011)\end{array}$} & \multirow{2}{*}{$\begin{array}{c}\text { BIS / ISI } \\
\text { Standard } \\
(2012)\end{array}$} \\
\hline & $\begin{array}{c}\text { Minimu } \\
\mathrm{m}\end{array}$ & $\begin{array}{c}\text { Maximu } \\
\mathrm{m}\end{array}$ & Minimum & Maximum & Minimum & Maximum & & \\
\hline Temp $\left({ }^{\circ} \mathrm{C}\right)$ & 26.5 & 29.9 & 26.5 & 29.4 & 26.2 & 29.8 & - & - \\
\hline $\mathrm{pH}$ (on scale) & 4.77 & 6.92 & 4.83 & 7.84 & 4.65 & 7.82 & $6.5-8.5$ & $6.5-8.5$ \\
\hline $\mathrm{EC}(\mu \mathrm{s} / \mathrm{Cm})$ & 41.8 & 1161 & 48.7 & 1112 & 44.5 & 737 & 1500 & - \\
\hline TDS (mg/l) & 29.6 & 826 & 27.9 & 788 & 31.5 & 522 & 500 & 500 \\
\hline $\mathrm{HCO}_{3}(\mathrm{mg} / \mathrm{l})$ & 5.07 & 213.62 & 12.06 & 452.38 & 5.03 & 175.92 & 500 & - \\
\hline $\mathrm{Cl}^{-}(\mathrm{mg} / \mathrm{l})$ & 5.2 & 289.32 & 1.92 & 248.08 & 2.08 & 208.45 & 250 & 250 \\
\hline $\mathrm{SO}_{4}{ }^{2-}(\mathrm{mg} / \mathrm{l})$ & 0.06 & 2.45 & 0.11 & 2.87 & 0.13 & 4.62 & 250 & 200 \\
\hline $\mathrm{Ca}^{2+}(\mathrm{mg} / \mathrm{l})$ & 1.61 & 50.05 & 1.61 & 95.27 & 0.81 & 59.74 & 75 & 75 \\
\hline $\mathrm{Mg}^{2+}(\mathrm{mg} / \mathrm{l})$ & 0.47 & 21.75 & 0.44 & 13.94 & 0.48 & 17 & 50 & 30 \\
\hline $\mathrm{Na}^{+}(\mathrm{mg} / \mathrm{l})$ & 2.1 & 178.2 & 1.67 & 290.59 & 1.99 & 406.4 & 200 & - \\
\hline $\mathrm{K}^{+}(\mathrm{mg} / \mathrm{l})$ & 0.48 & 245.1 & 0.16 & 130.25 & 0.45 & 215.6 & 12 & - \\
\hline T H (mg/l) & 8 & 178.14 & 6 & 288.23 & 4 & 182.15 & - & 200 \\
\hline
\end{tabular}

\subsubsection{Electrical Conductivity}

Electrical Conductivity is used to measure purity of water and also electric current flow. High electrical conductivity is regarded as pollution indicator.
The most advisable limit of Electrical Conductivity in drinking water is given as $1500 \mu \mathrm{S} / \mathrm{cm}$ (WHO). The 
EC of ground water is varying from $41.8-1161 \mu \mathrm{S} / \mathrm{cm}$ with a mean value of $333.19 \mu \mathrm{S} / \mathrm{cm}$. Higher EC indicates the rehab of salts in the ground water, which depends upon concentration, temperature and types of ions.

\subsubsection{Total Dissolved Solids}

TDS indicate the amount of inorganic chemicals in water solutions. As per WHO and ISI specifications TDS up to $500 \mathrm{mg} / \mathrm{l}$ is maximum limit. In the study area the TDS values varies between 27.9 - $826 \mathrm{mg} / \mathrm{l}$, indicating that most of the groundwater samples lies within the permissible limit, as in Table 2. High level of TDS in drinking water may be irksome to users due to its taste and this could also cause problems in water pipes and household applications.

This high content of TDS in sample may due to contamination from domestic waste and leaching of salts from soil into the groundwater.

Table: 2 Davis and De Wiest (1966)- classification on TDS

\begin{tabular}{llc}
\hline TDS $(\mathrm{mg} / \mathrm{l})$ & \multicolumn{1}{c}{ Classification } & Sample $\%$ \\
\hline \hline \multirow{2}{*}{500} & Desirable for drinking & 88.89 \\
$500-1,000$ & Permissible for drinking & 11.11 \\
$1000-3,000$ & Irrigation purpose & - \\
$>3,000$ & Infirm drinking \& irrigation & - \\
\hline
\end{tabular}

\subsubsection{Total Hardness}

Hardness is an important parameter in decreasing the toxic effect of poisonous element. Hardness is primarily caused by the dissolved mineral compounds calcium and magnesium although smaller contributions to hardness will also come from some other ions including iron and manganese. The total hardness varies from 4.0-288.23 mg/l with an mean value of $44.58 \mathrm{mg} / \mathrm{l}$. A maximum value of 288.23 $\mathrm{mg} / \mathrm{l}$ hardness was observed at sample 3 during monsoon season. Increase in hardness of water, may due to the deposition of magnesium and calcium content. Groundwater of the whole study area are within the permissible limit by ISI (2012). According to the classification of of groundwater showed in Table 3, based on total hardness, $80.24 \%$ of the total groundwater samples are soft; $14.81 \%$ belong to moderately hard and only $4.93 \%$ belong to hard. The analysis indicates that water in the study area is soft to hard. The quality is evaluated by comparing with the specifications of TH and TDS set by the WHO and ISI

Table: 3 Classification on Total Hardness Sawyer and McCarty(1967)

\begin{tabular}{llc}
\hline $\begin{array}{l}\text { Total } \\
\text { Hardness }\end{array}$ & Classification & $\begin{array}{c}\% \\
\text { of samples }\end{array}$ \\
\hline \hline $0-75$ & Soft & 88.24 \\
$75-150$ & Quite hard & 14.81 \\
$150-300$ & Hard & 4.93 \\
over 300 & Very hard & - \\
\hline
\end{tabular}

\subsubsection{Bicarbonate}

The value of bicarbonate was observed as 5.03$213.62 ; 12.06-452.38$ and $5.03-175.92 \mathrm{mg} / \mathrm{l}$ with a mean value of $53.62 \mathrm{mg} / \mathrm{l}$, from the study area. Sample 3 has maximum $(452.38 \mathrm{mg} / \mathrm{l})$ and sample 1 has minimum $(5.03 \mathrm{mg} / \mathrm{l})$. The standard limit of bicarbonate is $500 \mathrm{mg} / \mathrm{l}$, which indicates that all samples are within the desired limit. Bicarbinate is a main ion except in the groundwater, occuring near the coast. The high concentrarion of bicarbonate in the water points to the dominance of mineral dissolution [11].

\subsubsection{Chloride and Sulfates}

The chloride concentration serves as an indicator of pollution by sewage and is considered as tracer for groundwater contamination in the drinking water [12]. A high concentration of chlorides affects growth of vegetation and results in metal corrosion. The permissible limit for chloride is $250 \mathrm{mg} / \mathrm{l}$ as per ISI and WHO. Water with high chloride content usually has an unpleasant smell and taste while drinking and may be not good for agricultural purposes as well. In the study area, the concentration of chloride is between 5.20-289.32, 1.92-248.08 and 2.02-208.45 mg/l during the three seasons with a mean value of $56.13 \mathrm{mg} / \mathrm{l}$, relatively the higher concentration of chloride is observed from the sample 6, (289.32 mg/l) during pre-monsoon.

Sulfate is one of the major anion appear in natural water. The ISI permissible limit for sulfate $\left(\mathrm{SO}_{4}{ }^{2-}\right)$ 
concentration is 200 while WHO is $250 \mathrm{mg} / \mathrm{l}$. The sulfate concentration of groundwater in the study area ranges between 0.06 and $26.36 \mathrm{mg} / \mathrm{l}$ and has a mean value of $1.46 \mathrm{mg} / \mathrm{l}$, which indicates that all samples are within the licit limit.

\subsubsection{Sodium and Potassium}

The observed value of Sodium (1.67 to 406.4) varies from 2.1-178.2; 1.67-290.59 and 1.99-406.4 mg/l during the three seasons with an average of 48.28 $\mathrm{mg} / \mathrm{l}$. According to WHO, maximum permissible limit of sodium is $200 \mathrm{mg} / \mathrm{l}$. A few samples from the study area exceed the permissible limit. The maximum value of $406.4 \mathrm{mg} / \mathrm{l}$ sodium was observed at sample 22 during Post-monsoon season. The excess intake of sodium can cause blood pressure and other health problems in human beings. Ground water with high sodium content is not fit for agricultural purpose as well as it affects the water intake by plants.

The Potassium content in Neyyar River fluctuated between $\quad 0.48-245.1 ; \quad 0.16-130.25 ; \quad 0.45-215.6$

\subsection{Evaluation of Irrigation Water Quality with Respect to Different Standards from Graphical Representation}

Irrigation plays a dominant role in plant growth as well as crop yield. In order to classify the quality of groundwater for irrigation various determinants such as $\mathrm{Na} \%, \mathrm{SAR}, \mathrm{MHR}$ and PI are calculated. Statistical representation of irrigational quality parameters of the groundwater samples are presented in Table 4, 5, 6 .

\subsubsection{Sodium Percent (Na \%)}

The sodium in irrigation water is usually denoted as percent of sodium. According to Wilcox in all natural waters $\mathrm{Na} \%$ is a common parameter to assess its suitability for irrigational purposes. The sodium percent $(\mathrm{Na} \%)$, was obtained by calculating the relative proportion of cations as in equations 1 .

$$
\mathrm{Na} \%=\left(\mathrm{Na}^{+}+\mathrm{K}^{+}\right) \times 100 /\left[\mathrm{Ca}^{2+}+\mathrm{Mg}^{2+}+\mathrm{Na}^{+}+\mathrm{K}^{+}\right]
$$

Where all ions are expressed in meq/l, the Wilcox [13] diagram relating sodium percent and electrical conductivity shows that $82.71 \%$ of samples are excellent for irrigation while $16.05 \%$ of samples belong to Permissible level and $1.24 \%$ of the samples throughout the period of sampling. The average value of potassium is $20.13 \mathrm{mg} / \mathrm{l}$ with a maximum value of $245.10 \mathrm{mg} / \mathrm{l}$, which indicate the potassium form complexes in studied surroundings.

\subsubsection{Calcium and Magnesium}

The calcium $\left(\mathrm{Ca}^{2+}\right)$ and magnesium $\left(\mathrm{Mg}^{2+}\right)$ in waters are generally used to classify the suitability of water. Calcium and magnesium ions are both common in natural waters and both are essential elements for all organisms. The values of Calcium are between 0.81 $95.27 \mathrm{mg} / \mathrm{l}$. The permissible limit of calcium for drinking water is $75 \mathrm{mg} / \mathrm{l}$ as per ISI and WHO as in table above. This shows that few groundwater samples fall beyond the admissible limit.

Magnesium content in the samples varies from 0.44 $21.75 \mathrm{mg} / \mathrm{l}$, and the maximum permissible limit of magnesium content in the drinking water is $30 \mathrm{mg} / \mathrm{l}$ as per ISI while $50 \mathrm{mg} / \mathrm{l}$ according to WHO which shows that all the samples are within the legal limit.

are Doubtful for irrigation with an average values of $63.27 \mathrm{mg} / \mathrm{l}$ as in Table.5 (Figure 2).

\subsubsection{Permissible Index (PI)}

Based on the permissible index (PI), water suitability for classification in irrigation water was developed by Doneen [14]. The PI was calculated by the following equation 2.

$$
\mathrm{PI}=\left[\mathrm{Na}^{+}+\left(\mathrm{HCO}_{3}\right)^{0.5}\right] \times 100 /\left[\mathrm{Na}^{+}+\mathrm{Ca}^{2+}+\mathrm{Mg}^{2+}\right]
$$

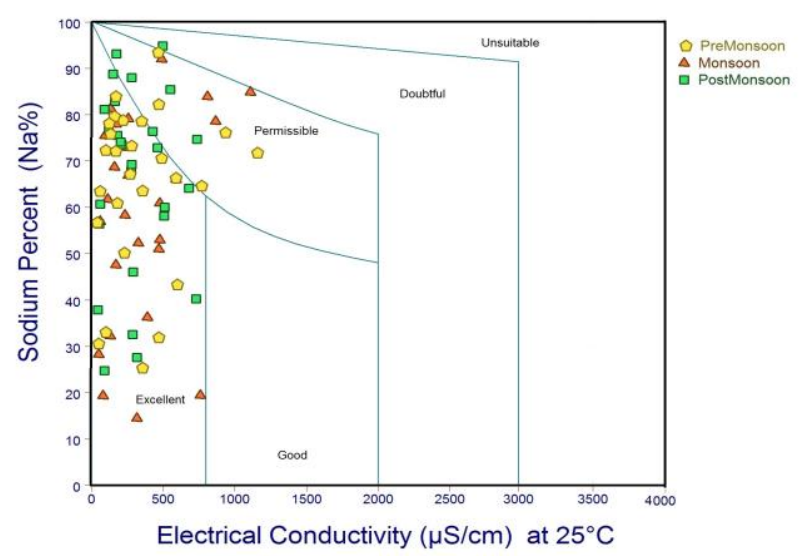

Figure 2: Irrigation Classification (Wilcox 1955) 
International Journal of Research in Advent Technology, Vol.7, No.5, May 2019

$$
\text { E-ISSN: 2321-9637 }
$$

\section{Available online at www.ijrat.org}

Table: 4 (Doneen 1964) - Classification based on PI

\begin{tabular}{lcc}
\hline Classification & PI Values & \% Of Samples \\
\hline \hline Excellent & $>75$ (Class I) & 92.59
\end{tabular}

Table: 5 Irrigational quality indices of ground water

\begin{tabular}{lccc}
\hline Specification & Minimum & Maximum & Average \\
\hline \hline $\mathrm{Na} \%$ & 14.45 & 94.91 & 63.27 \\
$\mathrm{PI}$ & 56.80 & 376.7 & 121.77 \\
$\mathrm{SAR}$ & 0.25 & 31.67 & 3.71 \\
MHR & 6.05 & 92.12 & 43.04 \\
\hline
\end{tabular}

*All Specification in (mg/l)

\subsubsection{Sodium Adsorption Ratio (SAR)}

Sodium adsorption ratio is the most commonly used method to evaluate the effects of exchangeable sodium on the physical condition of the soil [15]. SAR is estimated by the following formula.

$\mathrm{SAR}=\mathrm{Na} /[(\mathrm{Ca}+\mathrm{Mg}) / 2]^{0.5}(3)$

Water with high SAR values when used for irrigation may require soil adaptation to prevent damage to the soil, because soil may lose calcium and magnesium due to excess sodium content in the water. So this may reduce the ability of the soil to form stable cluster and loss of soil form. Then the soil becomes compact and impervious creating hindrance to crop production.

The values vary between 0.25 and 31.67 with an average of 3.71. The classified values are tabulated in Table 6 . The SAR values of all the samples are found within the range of excellent excluding the sample 21 which is found to be unsuitable for irrigation purpose.

\begin{tabular}{llc} 
Good & $25-75($ Class II $)$ & 7.41 \\
Unsuitable & $<25 \quad$ (Class III) & - \\
\hline
\end{tabular}

The PI values and other classifications, as per WHO for assessing groundwater for irrigation uses tabulated in Table 4. The PI values in the study area vary from 56.80 to 376.70 in the seasonal periods, with an average of 121.77 (Table 5).

According to the study, about $92.59 \%$ of samples falls under class I and only 7.41 belong to class II during all the seasons which indicate that waters are categorized is good for irrigation.

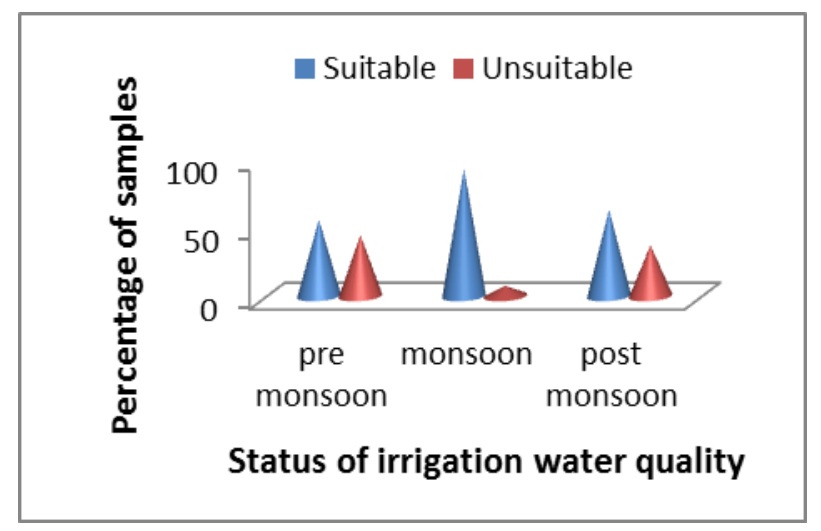

Figure 4: Status of irrigation water quality of groundwater as per MHR

\subsubsection{SAR-Conductivity (USSL)}

The USSL [16] diagram (Figure 2) considers the united effect based on EC and SAR, plotting EC against SAR, $48.15 \%$ samples of three seasons in groundwater samples lie in the class of C1S1 (low salinity-low sodium type) and $43.21 \%$ of the samples belong to C2-S1 type (medium salinity- low sodium) indicate sample is good for irrigation on all type of soil. Few samples from Pre-monsoon (2.40\%) fall into the C3-S1class (high salinity with low sodium) while $4.94 \%$ of monsoon and pre-monsoon samples lie within the class of C3-S2 and C3-S3 respectively. This can be used for irrigate salt tolerant and semi tolerant crops under favourable drainage condition. High salinity content in water in C4-S4 class, can affect the plant growth, while the medium type pose 
sodium hazard in fine-consistency soils and special soil administrative method are to be used during irrigation.

Table: 6 ( Todd 1959; Richards 1954) - Classification on SAR

\begin{tabular}{lcc}
\hline Classification & SAR Values & Samples \\
\hline \hline Excellent & $<10$ & 77 \\
Good & $10-18$ & 2 \\
Doubtful & $18-26$ & 1 \\
Unsuitable & $>26$ & 1 \\
\hline
\end{tabular}

\subsubsection{Magnesium Hazard}

In most waters calcium will be maintaining equilibrium with magnesium. Paliwal [17] developed magnesium hazard ratio for the effect of crop yield.

$$
\mathrm{MH}=\mathrm{Mg}^{2+} \times 100 /\left(\mathrm{Ca}^{2+}+\mathrm{Mg}^{2+}\right)
$$

The MHR Values range from 14.91 to $77.29 \%, 6.05$ to $60.02 \%$ and 7.58 to $92.12 \%$ during all the three seasons with an average of 43.04 as in Table 5 . Majority of the samples $(70.37 \%)$ during the study period is suitable for irrigation while $29.63 \%$ falls in the unsuitable category with magnesium hazard $>50$ $\%$ (Figure 4) shows during monsoon water is suitable for irrigation. Analysis shows that $29.63 \%$ samples are un-favourable for agricultural yield. Excess amount of $\mathrm{Mg}^{2+}$ changes the soil properties and reduce the plant growth.

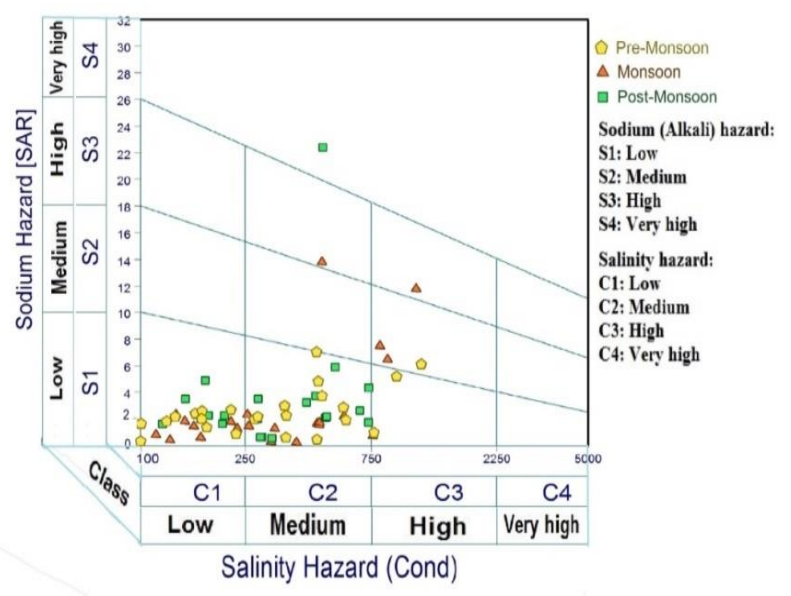

Figure: 3 SAR-Conductivity plot diagram (USSL 1954)

\subsection{Piper Diagram}

The hydro-chemical development of groundwater can be implied by plotting major cations and anions; the diagrams relive the problems related to geochemical evolution of groundwater. Piper [18] diagram reveals both similitude and dis- similitude amid groundwater samples, which tend together as similar groups. The diamond shaped areas are combination of both cations and anions ion of piper diagram (Figure 5), which clearly explaines the clusters in the area

The groundwater samples shows that in premonsoon, monsoon and post-monsoon about 22.22 $\%$ of the samples fall in the field I (alkali earth exceeds alkalies ); $77.77 \%$ of the samples fall in field 2 (alkalies exceeds alkaline earth) and $30.86 \%$ of the samples fall in field 3 (Weak acids exceeds strong acids); about $69.13 \%$ of the samples fall in the field 4 (Strong acids exceeds weak acids); $18.52 \%$ of the samples fall in field 5 Carbonate hardness (Secondary alkalinity) exceeds $50 \%$ (Chemical properties are dominated by alkaline earth and weak acids); $50.62 \%$ of the samples fall in field 7 Carbonate alkalinity (Primary salinity) exceeds 50\% (Chemical properties are dominated by alkaline earth and weak acids) and $14.82 \%$ of the samples fall in the field 9 Mixed types (No cation-anion pairs exceeds 50\%) and type 6 Non-carbonate hardness (Secondary salinity) exceeds $50 \%$ (Chemical properties are dominated by alkaline earth and strong acids) \& type 8 Carbonate alkalinity (Primary alkalinity) exceeds $50 \%$ (Chemical properties are dominated by alkalies and weak acids) are absent

The present study indicate that $\mathrm{Ca}-\mathrm{HCO}_{3}$, mixed $\mathrm{CaNaHCO}_{3}$ and $\mathrm{NaCl}$ type dominate and the plot shows that all of the samples fall under the subdivision of alkaline earths exceeds alkali metals and weak acidic anions exceed strong acidic anions, the presence of $\mathrm{NaCl}$ indicate that there is an ion exchange taken place in this area.. 


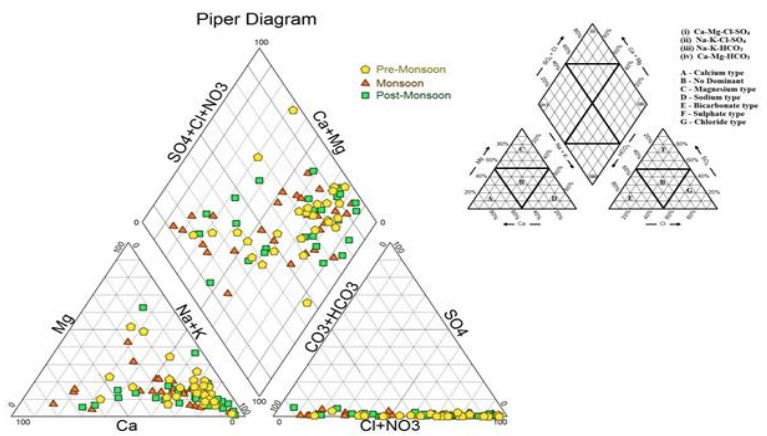

\subsection{Controlling Mechanism of Water Chemistry}

The groundwater quality for drinking and irrigation purposes was evaluated based on WHO standards. The groundwater quality is remarkably changed by the anthropogenic interventions and other nature occurrences. Gibbs diagram [19] is used to understand relationship of water composition and

aquifer lithological feature. The mechanism which control ground water chemistry are based on evaporation dominance, rock dominance and Rainfall dominance which is plotted by hydro-chemical data variation in the ratios of $\mathrm{Na}^{+} /\left(\mathrm{Na}^{+}+\mathrm{Ca}^{2+}\right)$ and $\mathrm{Cl}^{-}$ $/\left(\mathrm{Cl}^{-}+\mathrm{HCO}_{3}^{-}\right)$with TDS.

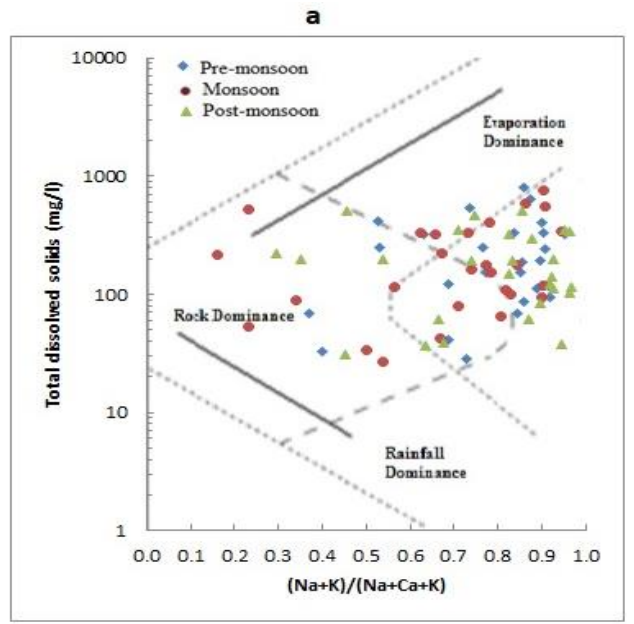

Figure: 5 Piper diagrams

The rock-weathering dominance suggest that the chemical composition of water were mainly controlled by weathering reactions, indicating that the silicate weathering is the dominant process for supply of the calcium ions to the groundwater and there is slight affinity towards the evaporation domain which reflects the precipitation of $\mathrm{CaCO}_{3}$ from solution, leaving $\mathrm{Na}^{+}$and $\mathrm{Cl}^{-}$as the dominant ionic constituents and there must be accepting as reflecting of major influence on the solute composition of stream water (Figure 6).

Figure 6: Rock-weathering dominance diagram (Gibbs 1970) 
Table: 7 Water quality statics and its purposes

\begin{tabular}{ccll}
\hline Sl.No: & WQI & Water Quality Status (WQS) & Purposes \\
\hline 1 & $0-25$ & Excellent & Drinking, irrigation and industrial \\
2 & $26-50$ & Good & Drinking, irrigation and industrial \\
3 & $51-75$ & Poor & irrigation and industrial \\
4 & $76-100$ & Very Poor & irrigation \\
5 & $>100$ & Unfit for drinking and fish culture & Proper treatment required before use \\
\hline
\end{tabular}

\subsection{Water Quality Index}

The overall water qualities of Neyyar basin groundwater was obtained for creating the water quality index (WQI). WQI has been obtained by using the standards index for drinking recommended by the WHO, ISI. The weighted arithmetic index method [20] [21] has been used for the calculation of WQI of the water body tabulated in Table 8 and water quality statics and its classification tabulated in Table 7.

$\mathrm{WQI}=\Sigma \mathrm{Q}_{\mathrm{n}} \mathrm{W}_{\mathrm{n}} / \Sigma \mathrm{W}_{\mathrm{n}}$
Where $Q_{n}$ is the quality rating of $n^{\text {th }}$ water quality parameter, $W_{n}$ is the unit weight of nth water quality parameter. The quality rating $\mathrm{Q}_{\mathrm{n}}$ is calculated using the equation

$\mathrm{Q}_{\mathrm{n}}=100\left[\left(\mathrm{~V}_{\mathrm{n}}-\mathrm{V}_{\mathrm{i}}\right) /\left(\mathrm{V}_{\mathrm{s}}-\mathrm{V}_{\mathrm{i}}\right)\right]$

Where $V_{n}$ is the actual amount of nth parameter present, $\mathrm{V}_{\mathrm{i}}$ is the ideal value of the parameter $\left[\mathrm{V}_{\mathrm{i}}=0\right.$, except for $\left(\mathrm{P}^{\mathrm{H}} \mathrm{V}_{\mathrm{i}}=7\right)$ and Do $\left.\left(\mathrm{V}_{\mathrm{i}}=14.6 \mathrm{mg} / \mathrm{l}\right)\right], \mathrm{V}_{\mathrm{s}}$ is the standard permissible value for the $\mathrm{n}^{\text {th }}$ water quality parameter.

$$
\mathrm{K}=\left[1 / \Sigma 1 / \mathrm{V}_{\mathrm{n}}=1,2,3 \ldots \mathrm{n}\right]
$$

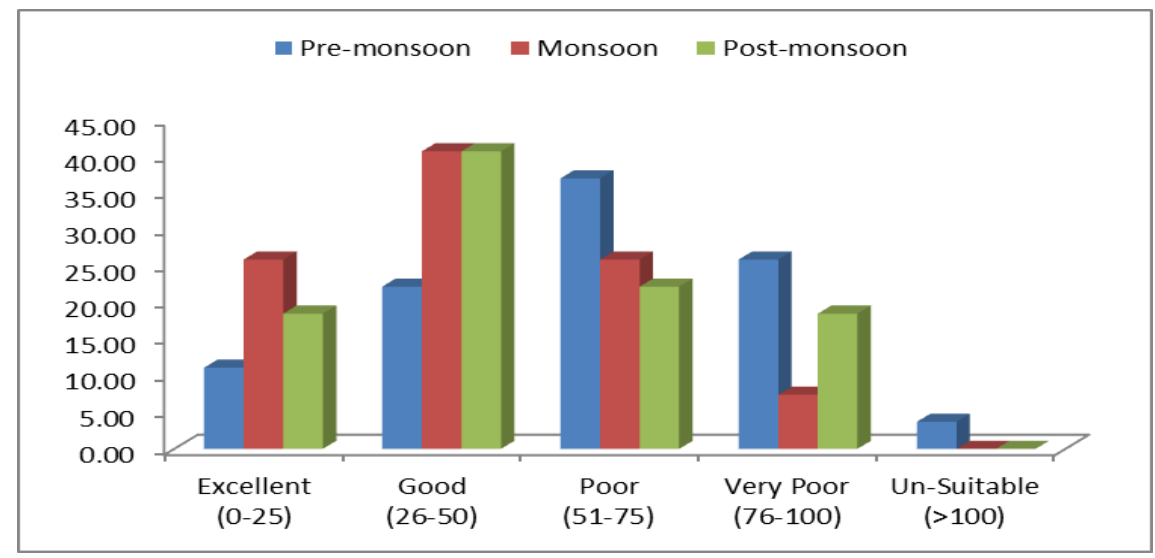

Figure 7: Variation of WQI during different seasons

\subsection{WQI Analysis}

The chemistry of groundwater is often used as a tool for astute the drinking and irrigation water quality.
WQI is an essential for identifying the water quality and sustainability of drinking water.

A total of 27 site samples were analyzed for WQI of all the threeseasons' samples. Among these, $18.52 \%$ of samples showed excellent, $34.57 \%$ of the samples under good category, $28.40 \%$ of the samples show 


\section{E-ISSN: 2321-9637}

\section{Available online at www.ijrat.org}

Poor, $17.29 \%$ of the samples fell under very poor and only $1.23 \%$ of the water, unsuitable for drinking purpose.

This may be due to rock water interaction influencing silicate weathering and the high content of Electrical Conductivity, chloride, sodium, calcium and ion exchange interaction which may also cause anthropogenic activity clearly suggest that rockweathering interaction process is the main source for degrading the water quality in the study area.

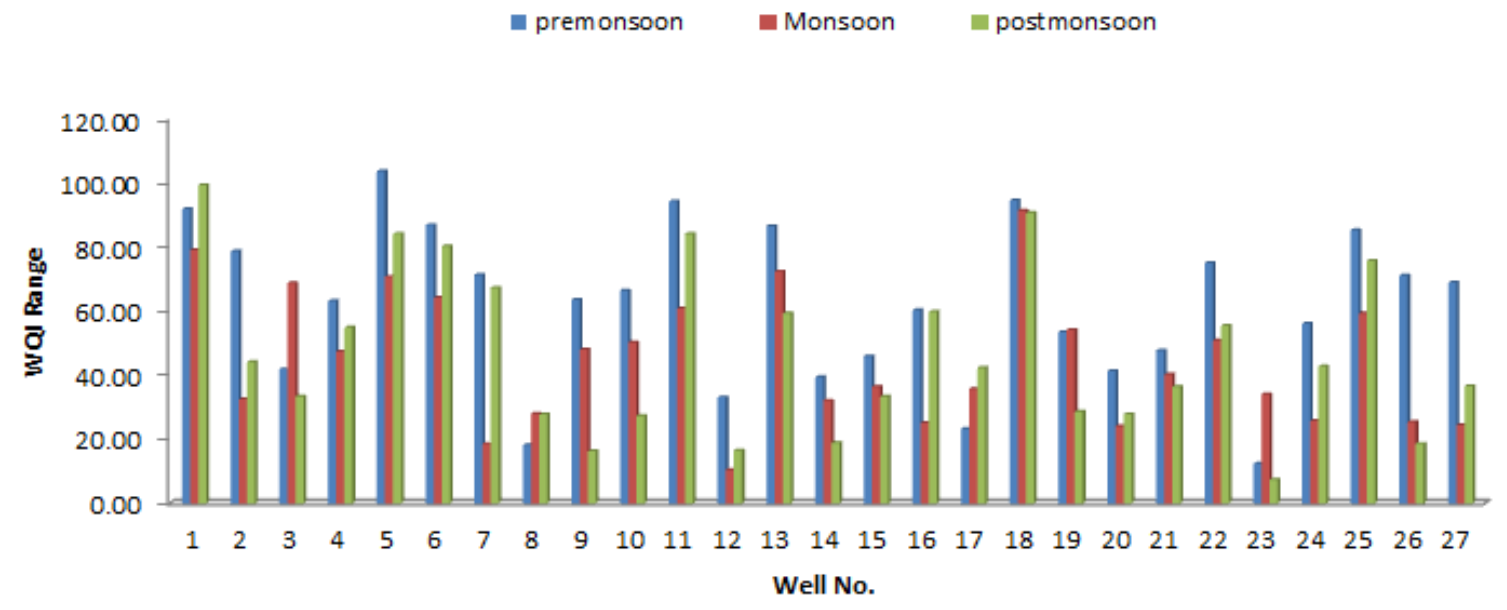

Figure 8: WQI Values graph of studied samples

Table: 8 Relative weights $\left(\mathrm{W}_{\mathrm{n}}\right)$ of the Specifications used for WQI calculation

\begin{tabular}{|c|c|c|c|c|}
\hline Sl.No & Specifications & $\operatorname{Standards}\left(\mathrm{S}_{\mathrm{n}}\right)$ & $\begin{array}{c}\text { Recommended } \\
\text { Agency }\end{array}$ & $\begin{array}{c}\text { Unit } \\
\text { Weight }\left(\mathrm{W}_{\mathrm{n}}\right)\end{array}$ \\
\hline 1 & $\mathrm{P}^{\mathrm{H}}$ & $6.5-8.5$ & ISI/WHO & 0.618174 \\
\hline 2 & E C & 300 & ISI & 0.017515 \\
\hline 3 & TDS & 500 & ISI/WHO & 0.010509 \\
\hline 4 & $\begin{array}{c}\text { Total } \\
\text { Alkalinity }\end{array}$ & 120 & ISI & 0.043787 \\
\hline 5 & $\begin{array}{c}\text { Total } \\
\text { Hardness }\end{array}$ & 300 & ISI & 0.017515 \\
\hline 6 & Calcium & 75 & ISI/WHO & 0.07006 \\
\hline 7 & Magnesium & 30 & ISI & 0.175149 \\
\hline 8 & Chloride & 250 & ISI/WHO & 0.021018 \\
\hline 9 & Sulphate & 200 & ISI & 0.026272 \\
\hline \multicolumn{4}{|c|}{$\Sigma \mathrm{W}_{\mathrm{n}=}$} & 1 \\
\hline
\end{tabular}

*All Specification are in $(\mathrm{mg} / \mathrm{l})$ except $\mathrm{pH}$ and $\mathrm{EC}(\mu \mathrm{s} / \mathrm{cm})$

\subsection{Water Quality for Industrial Purpose}


The quality requirements for industrial water range may differ and almost every industrial has its own standards. Industries regularly agonize from the unenviable effects of corrosion, which is caused by chemical reaction on metals and damages on over Layer crust is due to unwanted deposition of $\mathrm{CaCO}_{3}$ on metal surface, which are alsodue to thepoor water quality. The following criteria have been used forchecking the bio-fouling of crust and corrosive properties of the water [22] [23]

a. water with $\mathrm{HCO}_{3}$ more than $500 \mathrm{mg} / \mathrm{l}$ or $\mathrm{SO}_{4}$ more than $150 \mathrm{mg} / \mathrm{l}$ may cause bio-fouling of crust.

b. water with $\mathrm{pH}<7$ or TDS more than 1000 $\mathrm{mg} / \mathrm{l}$ or $\mathrm{Cl}$ more than $400 \mathrm{mg} / \mathrm{l}$ may cause corrosion.

About $3.7 \%$ of the sample exceeds the limit of 500 $\mathrm{mg} / \mathrm{l}$ in $\mathrm{HCO}_{3}$ in monsoon season. Such water samples can damage crust on metal surfaces and hence notsuggested for industries. The groundwater is not free from corrosion, since most of the $\mathrm{pH}$ is less than 7. However the concentration of TDS and $\mathrm{Cl}$ is not exceeds the limit of $1000 \mathrm{mg} / \mathrm{l}$ and $500 \mathrm{mg} / \mathrm{l}$ respectively, in any of the seasons.

\section{CONCLUSIONS}

Groundwater is an imperative source for agricultural and domestic purposes and also for other development activities. The current study is done on open wells and study area is always under pressure due to growing populace and extra urge for fresh water. The piper diagram shows that $\mathrm{Ca}-\mathrm{HCO}_{3}$ mixed $\mathrm{CaNaHCO}_{3}$ and $\mathrm{NaCl}$ are dominated water type. $\mathrm{pH}$ values from analysed data shows that, groundwater is slightly acidic in nature, as reported by many in lateritic terrain. The aptness of water for irrigation is assessed based on $\mathrm{Na} \%$, PI and SAR, shows that most of the sample suitable for irrigation, but few samples are beyond the licit limits. It has been concluded that, water from the study area is fit for drinking and agriculture, asideelect samples which are exceeding the limits may due to anthropogenic intervention and those samples were reluctant for agriculture. Based on the Gibbs diagram, evaporationand rock-waterinteraction are two main responsible processes for changing the chemical composition of groundwater. Based on WQI, majority of the groundwater samples are suitable for drinking and irrigation, but not recommended for industrial purposes, due to low $\mathrm{pH}$. The silicate weathering, anthropogenic interventions and urbanization are the main factors influencing groundwater quality in the study area. Pre-treatment on sewage before draining into adjoining rivers / irrigation channels is the primary solution to preserve and improve the groundwater quality. To improve the quality of water, the Government and other organization should provide the virtuous support to design, water harvesting and artificial recharge methods and it should be implemented to overcome fresh water scarcity and to benefit future generation.

\section{ACKNOWLEDGMENT}

The authors are thankful to Kerala State Council for Science, Technology and Environment (KSCSTE) for funding and the Executive Director, Centre for Water Resources Development and Management (CWRDM) for providing necessary facilities and support to carry out the study.

\section{REFERENCES}

[1] UNEP (2003). Source book of alternative technologies for freshwater augmentation in west Asia, United Nations Environment ProgramInternational Environmental Technology Centre.

[2] Izuka, SK; and Gingerich, SB; (1998). Estimation of the depth to the fresh-water/saltwater interface from vertical head gradients in wells in coastal and island aquifers. Hydrogeology journal, V.6, pp.365-373.

[3] Feseker, T. (2007) Numerical studies on saltwater intrusion in a coastal aquifer in northwestern Germany. Hydrogeology journal v.5, pp. 267-279.

[4] Gallardo, AH; and Murali, A. (2007). Modelling the dynamics of the freshwater-saltwater interface in response to construction activities at a coastal site. Int. Jour. Environ. Sci. \& Tech; V.4 (3), 285-294.

[5] Mohsen, MS; Singh, VP; Amer, AM. (1990). A note on saltwater intrusion in coastal aquifers. Water Resources Management, v.4 (2), pp. 123134.

[6] Samsuddin, M. (1980) Quantitative Geomorphological studies of the Neyyar River basin, Trivandrum District, Kerala state. Professional Paper.9 Centre for Earth Science Studies.

[7] Burrough PA, McDonnell RA (1998) Principles of geographical information systems. Oxford University Press, Oxford, P 333

[8] APHA (2005) Standard methods for the examination of water and waste water, $19^{\text {th }}$ edu. 
American public-Health Association, Washington, DC

[9] WHO (2004) Guidelines for drinking water quality. World Health Organization, Geneva.

[10] ISI (2012) Indian Standard Specification for drinking water. ISI 10500, New Delhi.

[11] Stumm W, Morgan JJ (1966) Aquatic chemistry. Wiley, New York, P 1022

[12] Loizidou M, Kapetanios EG (1993) Effect of leachate from landfills on underground quality. Sci Total Environ 128:69-81. doi: 10.1016/00489697(93)90180E

[13] Wilcox, LV. (1955) Classification and use of irrigation water. USD circular No.969, PP.19

[14] Doneen, LD. (1964) Notes on water quality in agriculture. Water Science and Engineering, University of California, Davis.

[15] Todd DK (1980) Groundwater hydrology [M], 2nd edu. Wiley, New york, P 535

[16] USSL (1954) Diagnosis and improvement of saline and alkali soil. USDA Hand Book No. 60, Washington

[17] Paliwal, KV. (1972) Irrigation with saline water [Z]. Monogram No.2 (new series). IARI, New Delhi, PP. 198
[18] Piper, AM. (1944) A graphical interpretation of water analysis. Trans Am Geophys Union 25:914-928.

[19] Gibbs, RJ. (1970) Mechanism controlling world water chemistry science 170:795-840.

[20] Brown, RM; McClellan, NI; Deininger, RA; Tozer, RG. (1970) A water quality index-do we dare? Water sew works 117:339-343.

[21] Chatterjee, C; Raziuddin, M. Determination of water quality index of a degraded river in Asanol industrial area, Raniganj, Burdwan, west Bengal, Nature, Environment and pollution Technology, 1(2), 2002, pp. 181-189.

[22] Johnson, EE. (1983 Ground water and wells. $1^{\text {st }}$ Indian edition, Jain Brothers pp. 440

[23] Subba Rao, N; Surya Rao, P; Venktram Reddy, G; Nagamani, M; Vidyasagar, G; Satyanarayana, NLVV. (2012) chemical characteristics of groundwater and assessment of groundwater quality in varaha river basin, Visakhapatnam district, Andhra Pradesh, India. Environ Monit Assess 184:5189-5214. 